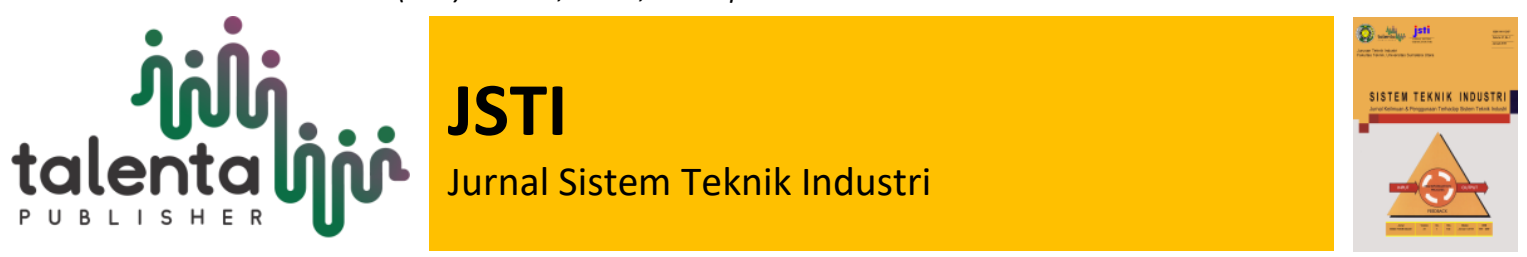

\title{
Performance Measurement Analysis Based on Baldrige Excellence Framework in Palm Oil Company
}

\author{
Tania Alda ${ }^{1}$ \\ ${ }^{I}$ Department of Industrial Engineering, Faculty of Engineering, Universitas Sumatera Utara, Medan, \\ Indonesia
}

\begin{abstract}
Performance measurement is needed to evaluate the condition of the company. Based on preliminary discussions with the company, the company's performance measurement still focused on the financial aspects and has not carried out a comprehensive performance measurement involving other aspects of the company that is also important to know its performance. So, the company does not know the substantive condition of the company. The purpose of this research is to identify the position by using the Baldrige excellence framework (BEF) so that the company knows its condition and can improve and enhance the company's performance. Baldrige excellence framework used to identify the position of the company using seven criteria, namely leadership, strategy, customers, knowledge management, workforce, operations, and results. After identifying the company's position with the baldrige excellence framework, then analysis is carried out to find the root cause of the problem based on the Baldrige Excellence Framework assessment using a fishbone diagram. The maximum score of the Baldrige Excellence Framework is 1000. Based on the assessment, the results showed that the company was in the Early Result category with a value of 314,25 . It means that the company is already at a good early stage to achieve the company's excellent performance.
\end{abstract}

Keyword: Baldrige Excellence Framework (BEF), Performance, Company Position, Fishbone Diagram, Palm Oil Company

\begin{abstract}
Abstrak. Pengukuran kinerja diperlukan untuk mengevaluasi kondisi perusahaan dalam upaya mencapai sasaran dan tujuan akhir perusahaan. Berdasarkan diskusi awal dengan pihak perusahaan, pengukuran kinerja yang dilakukan perusahaan selama ini masih fokus terhadap aspek keuangan dan belum melakukan pengukuran kinerja secara komprehensif dengan melibatkan aspek-aspek lain dalam perusahaan yang juga penting untuk diketahui kinerjanya. Hal tersebut mengakibatkan perusahaan tidak mengetahui gambaran yang sebenarnya mengenai kondisi perusahaan. Tujuan dari penelitian ini untuk mengidentifikasi posisi perusahaan dengan menggunakan baldrige excellence framework (BEF) sehingga perusahaan mengetahui kondisinya dan dapat memperbaiki serta meningkatkan kinerja perusahaannya. Baldrige excellence framework digunakan untuk mengidentifikasi posisi perusahaan dengan menggunakan 7 kriteria yaitu kepemimpinan, strategi, pelanggan, manajemen pengetahuan, tenaga kerja, operasi dan hasil. Setelah diidentifikasi posisi perusahaan dengan baldrige excellence framework maka selanjutnya dilakukan analisis untuk menemukan akar penyebab masalah berdasarkan penilaian baldrige excellence framework dengan menggunakan fishbone diagram. Skor maksimum dari Baldrige Excellence Framework adalah 1000. Berdasarkan penilaian, diperoleh hasil bahwa perusahaan berada pada kategori Early Result dengan nilai 314,25. Hal ini menunjukkan
\end{abstract}

*Corresponding author at: Jln. Almameter Kampus USU, Medan 20155, North Sumatera, Indonesia

E-mail address: taniaalda@usu.ac.id 
bahwa perusahaan telah berada pada tahap pencapaian awal yang baik dalam upaya mencapai kinerja ekselen perusahaan.

Kata Kunci: Baldrige Excellence Framework (BEF), Kinerja, Posisi Perusahaan, Fishbone Diagram, Perusahaan Kelapa Sawit

Received 15 March 2021 | Revised 08 June 2021 | Accepted 12 July 2021

\section{Introduction}

Performance measurement is needed to evaluate the company so that the company can achieve its goals and objectives. Based on preliminary discussions with the company, the company's performance measurement is still focused on the financial aspects and has not carried out a comprehensive performance measurement involving others aspects of the company that is also important to know its performance. One way that companies can survive and exceed in competitive competition is by measuring performance.

Performance measurement carried out to improve and increase the performance of the organization/company on an ongoing basis. This is a necessity due to increasingly competitive competition between companies. Performance measurement is needed so that the company knows its position so that improvements are made and give an impact on increasing the company's productivity [1].

The problem faced by this oil palm company is that it has not carried out a comprehensive performance measurement and make the company does not know the fact of the company's condition. Based on this, it is necessary to measure performance comprehensively by involving all aspects within the company.

The solution to the problems, by using the Baldrige Excellence Framework (BEF) to identify the company's position, then using the Fishbone Diagram, an analysis carried out to find the root cause of the problem based on the Baldrige Excellence Framework assessment.

Baldrige Excellence Framework aims to assist companies in assessing company performance regardless of the size of the company whether it is a new company, a growing company, or a company that has been around for many years. The company can know the condition of the company as a whole and can assist the company in identifying the strengths and weaknesses of the company so that it can face business competition and long-term challenges. Baldrige Excellence Framework consists of 7 criteria: leadership, strategy, customers, knowledge management, workforce, operations, and results [2][3]. Baldrige excellence framework has been used by many companies in the manufacturing, service, small business, education, health, and non-profit sectors to improve company quality and performance [4].

Based on the explanation above, this study attempts to measure performance comprehensively by involving other aspects besides financial aspects so that, the company's position can be identified based on the Baldrige Excellence Framework, and then using the Fishbone Diagram, an analysis carried out to find the causes of the problem. 


\section{Literature Review}

Baldrige Excellence Framework is a framework for assessing company performance. Baldrige Excellence Framework empowers every company to achieve goals, improve results and be more competitive. Baldrige Excellence Framework consists of seven criteria: leadership, strategy, customers, knowledge management, operations, workforce, and results. From seven criteria, described into several more specific criteria and become the basis for the assessment using the ADLI approach (Approach, Deployment, Learning, and Integration) and the LTCI approach (Levels, Trends, Comparison, and Integration) [2].

By using the Baldrige Excellence Framework, the company can identify every strength and weakness. So the company can improve from various aspects of the company and can develop future improvement plans. Besides, the Baldrige Excellence Framework provides a framework for leading to superior performance for every company.

\section{Methodology}

This research was conducted in the palm oil company in Deli Serdang-North Sumatera. The first begins by identifying the problem in the company, namely all this time the company measuring the company's performance based on financial aspects and not measuring performance comprehensively. Based on this problem, a study was conducted to determine the company's position based on the Baldrige Excellence Framework. The stages carried out in this study are divided into 3, namely the first stage, an observation, and data collection, both primary data and secondary data. Data collection was carried out to identify the company's position based on the Baldrige Excellence Framework. Primary data collection was carried out by observation to observe the company's condition, interviews with company leaders, employees, and stakeholders, and by distributing questionnaires. Secondary data based on journals and previous research. The second stage is to perform data processing by conducting an assessment using ADLI (Approach, Deployment, Learning, and Integration) and LTCI (Levels, Trends, Comparison, and Integration). The third stage, the analysis stage to find the cause of the problem with the Fishbone Diagram.

\section{Results and Discussions}

Assessment of the condition of palm oil company based on the Baldrige Excellence Framework consists of based on process criteria and based on outcome criteria. The assessment for the process criteria consists of leadership, strategy, customers, knowledge management, workforce, and operations.

The leadership criteria consist of senior leadership and Governance and Societal Contributions. The strategy criteria consist of strategy development and strategy implementation. Customer criteria consist of Customer Expectations and customer engagement. The criteria for measurement, analysis, and knowledge management consist of Measurement, Analysis, and Improvement of Organizational Performance and Information and Knowledge Management. 
Workforce criteria consist of workforce environment and workforce engagement. The operation criteria consist of the work process and operational effectiveness [2]. Assessment of process criteria uses the ADLI approach, namely approach (method/system/procedure), deployment (deployment/application), learning (learning), and integration (integration) [5][6] .

The assessment for the outcome criteria consists of an assessment of the results of the products and processes, the results of the customer criteria, the results of the workforce criteria, the results of the governance and leadership criteria, and the results of the financial \& market criteria. In assessing the results criteria using the LTCI approach, namely levels (level of performance achievement), trends (level of improvement/growth in performance), comparison (comparison), and integration (integration) [5][6].

After assessing the seven criteria based on the Baldrige Excellence Framework for both the process criteria (using the ADLI approach) and the outcome criteria (using the LTCI approach), a final assessment is carried out for the condition of the company.

The final assessment is the sum of the process criteria assessment and the outcome criteria assessment. This assessment obtaining from the results of interviews, observations, distributing questionnaires, and examining related documents. The maximum score for each criterion is a stipulation based on the Baldrige Excellence Framework [7]. The final assessment of process criteria and results can be seen in Table 1 .

Table 1 Assessment of Company Condition Based on the Baldrige Excellence Framework

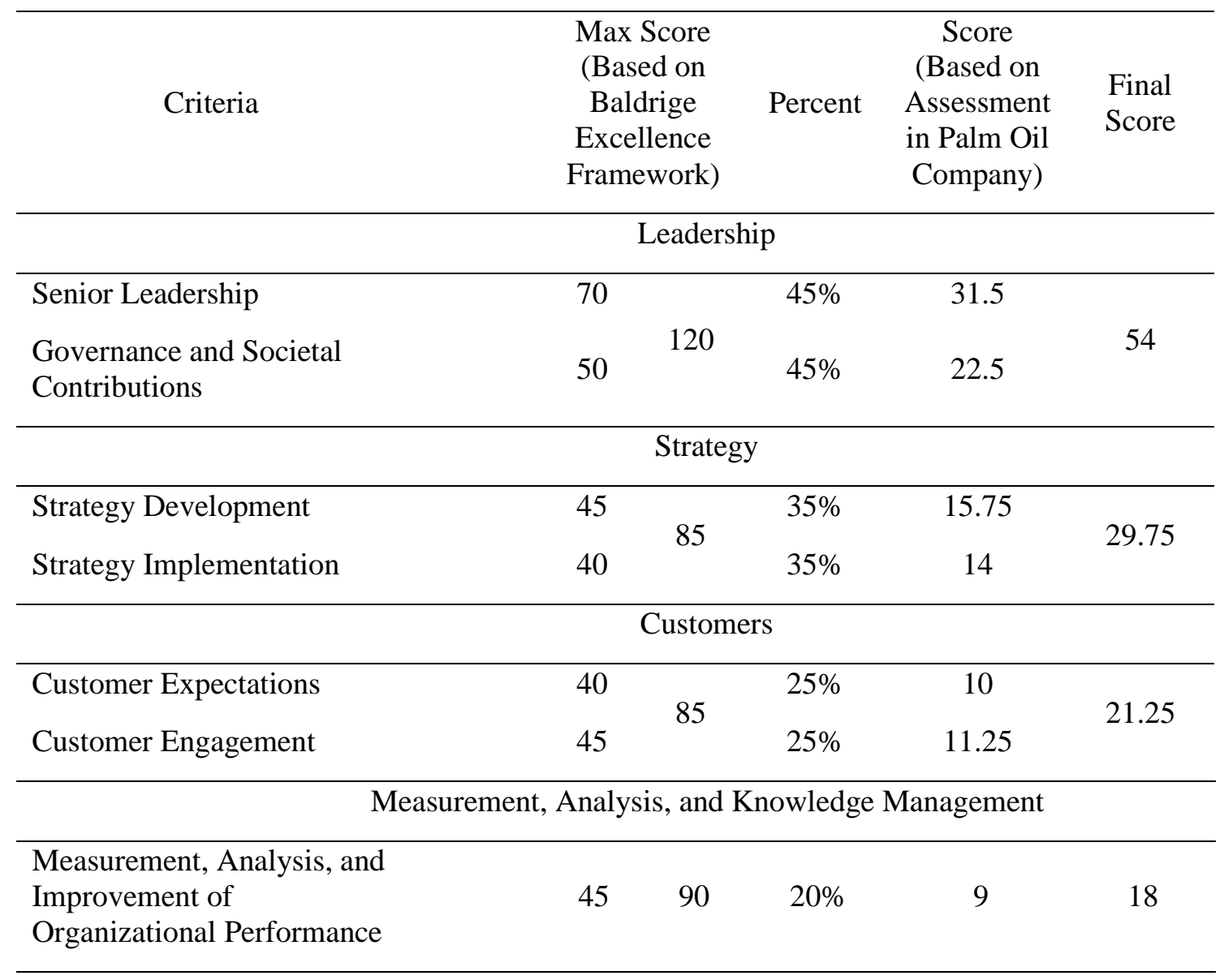


Information and Knowledge

Management

45

$20 \%$

9

\begin{tabular}{lccccc}
\hline \multicolumn{7}{c}{ Workforce } \\
Workforce Environment & 40 & 85 & $45 \%$ & 18 & 38.25 \\
Workforce Engagement & 45 & & $45 \%$ & 20.25 & \\
\hline & \multicolumn{7}{c}{ Operations } \\
\hline Work Processes & 45 & 85 & $40 \%$ & 18 & 34 \\
Operational Effectiveness & 40 & & $40 \%$ & 16 &
\end{tabular}

Final Score for Process Criteria

195.25

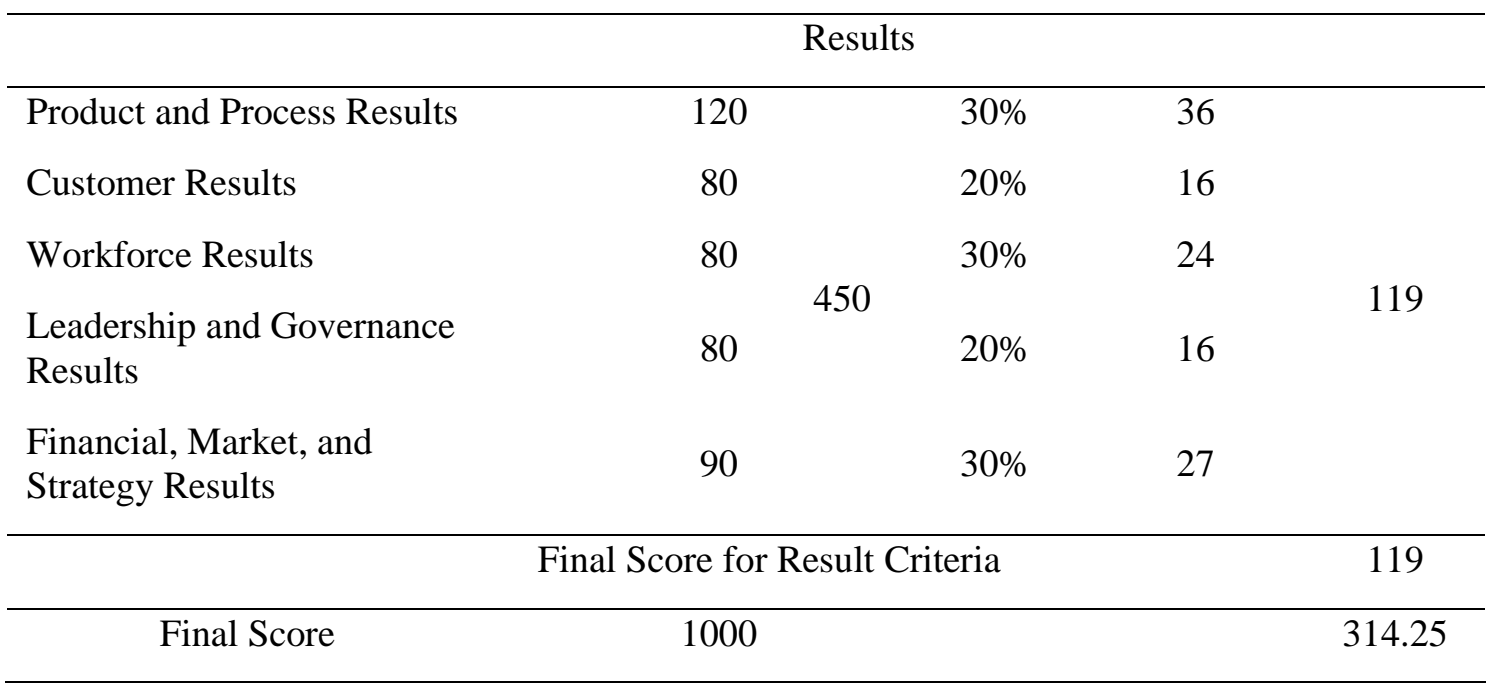

The maximum score of the Baldrige Excellence Framework is 1000, while based on the assessment by conducting interviews, observations, distributing questionnaires and observing documents, the company gets a score of 314.25 so that there is a gap of 685.75 . The graph of the comparison between the maximum score of Baldrige Excellence Framework and the assessment score in Palm Oil Company can be seen in Figure 1 and Figure 2. 


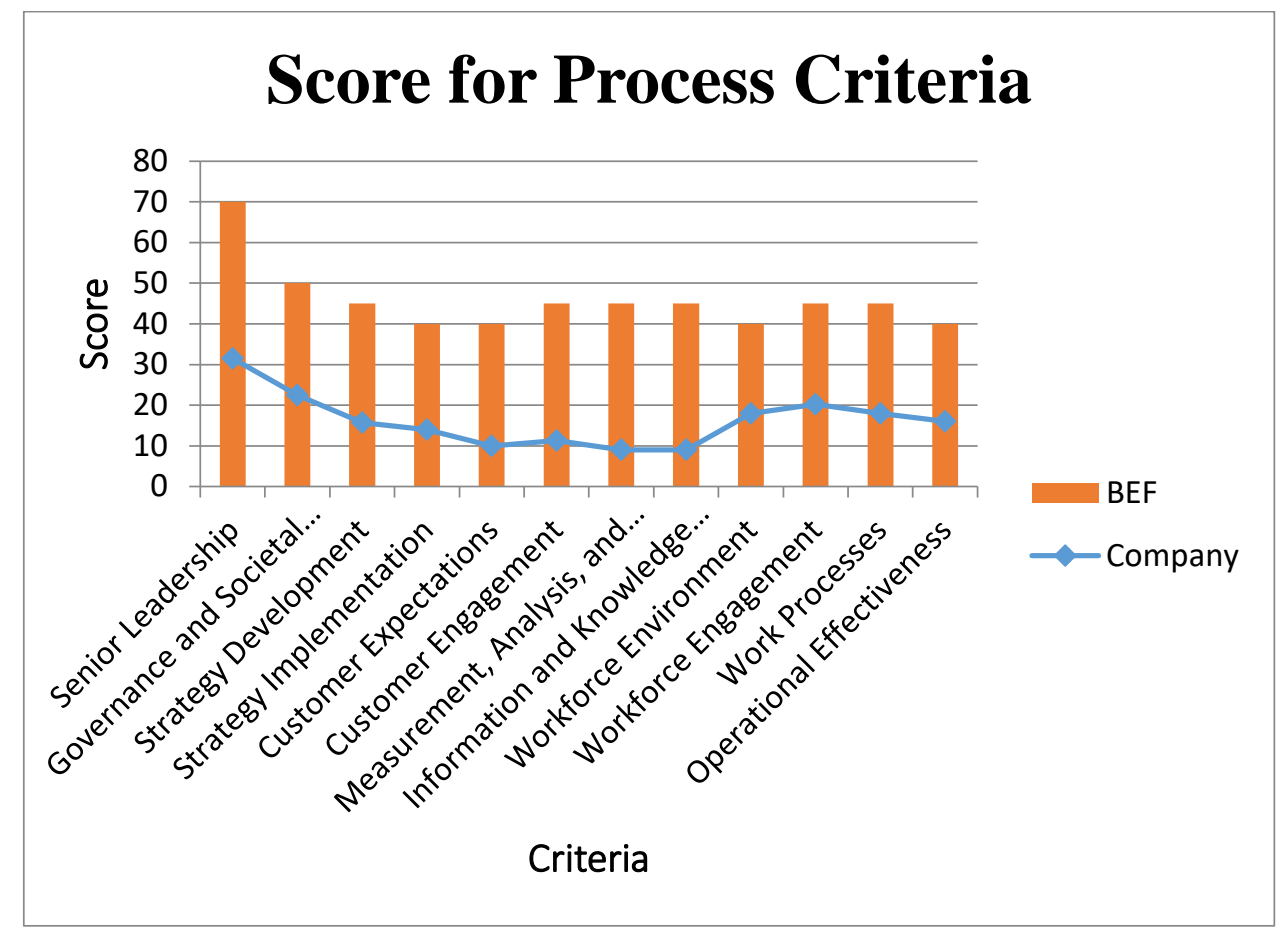

Figure 1 Score for Process Criteria

In Figure 1, it can be seen that comparison between the maximum score of Baldrige Excellence Framework and the assessment score for process criteria in Palm Oil Company.

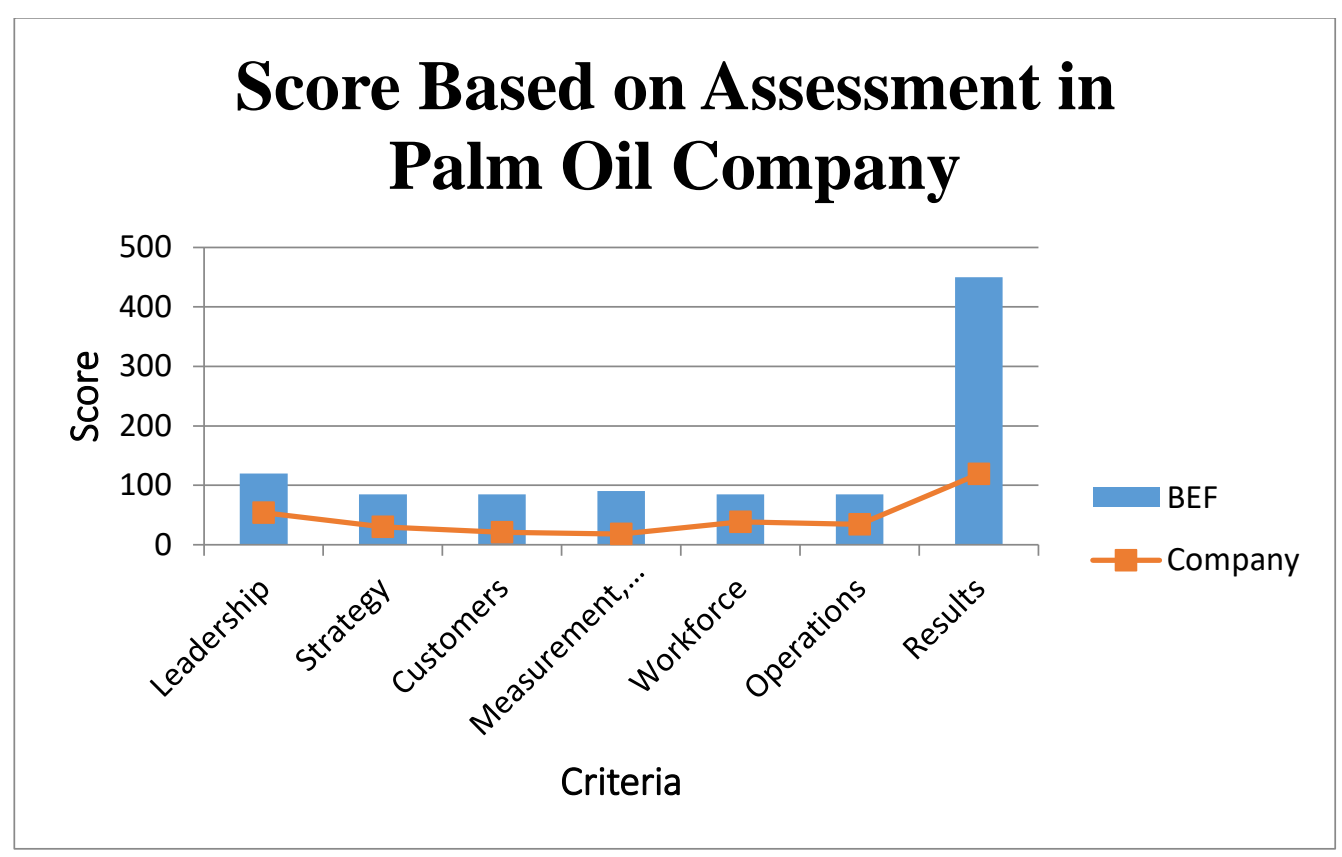

Figure 2 Score Based on Assessment in Palm Oil Company

In Figure 2, it can be seen that comparison between the maximum score of Baldrige Excellence Framework and the assessment score for 7 criteria: leadership, strategy, customers, knowledge management, workforce, operations, and results. 
After assessing the company's performance comprehensively using the Baldrige Excellence Framework, the next step is to determine the company's position based on the level, which can be seen in Table 2 [5][6].

Table 2 Level of The Company Based on The Assessment

\begin{tabular}{lc}
\hline \multicolumn{1}{c}{ Level } & Score \\
\hline Early Development & $0-250$ \\
Early Result & $251-350$ \\
Early Improvement & $351-450$ \\
Good to Excellence & $451-550$ \\
Emerging Industry Leader & $551-650$ \\
Industry Leader & $651-750$ \\
Benchmark Leader & $751-875$ \\
World Class Leader & $876-1000$ \\
\hline
\end{tabular}

Based on the assessment carried out from the process criteria and result criteria, the overall value obtained at the palm oil processing company for this research is 314.25 . It indicates that this company is at the early result level.

To find the causes for not optimal company achievement based on the Baldrige Excellence Framework, a Fishbone Diagram will be used to find the causes for not optimal company achievement [8][9]. The Fishbone Diagram based on the assessment carried out on oil palm processing companies can be seen in Figure 3 and Figure 4.

The leadership criteria are the driving force for other criteria, namely the criteria for strategy, customers, results, knowledge management, operations, and workforce [10]. Leadership is a starter in the Baldrige framework. Without good leadership, culture will not change, and organizational planning will not work [11]. The Leadership criteria has the ability to make changes in the system and guides every system of strategy and every process of excellence achievement [12]. It is in line with the results of observations and interviews conducted at this oil palm processing company. Based on the results of discussions with company leaders and employees, the criteria for leadership, strategy, and workforce are criteria that have a significant influence on others criteria. These three criteria serve as a driving force for others criteria in improving company performance. In other words, human resource factors influence improving company performance. 


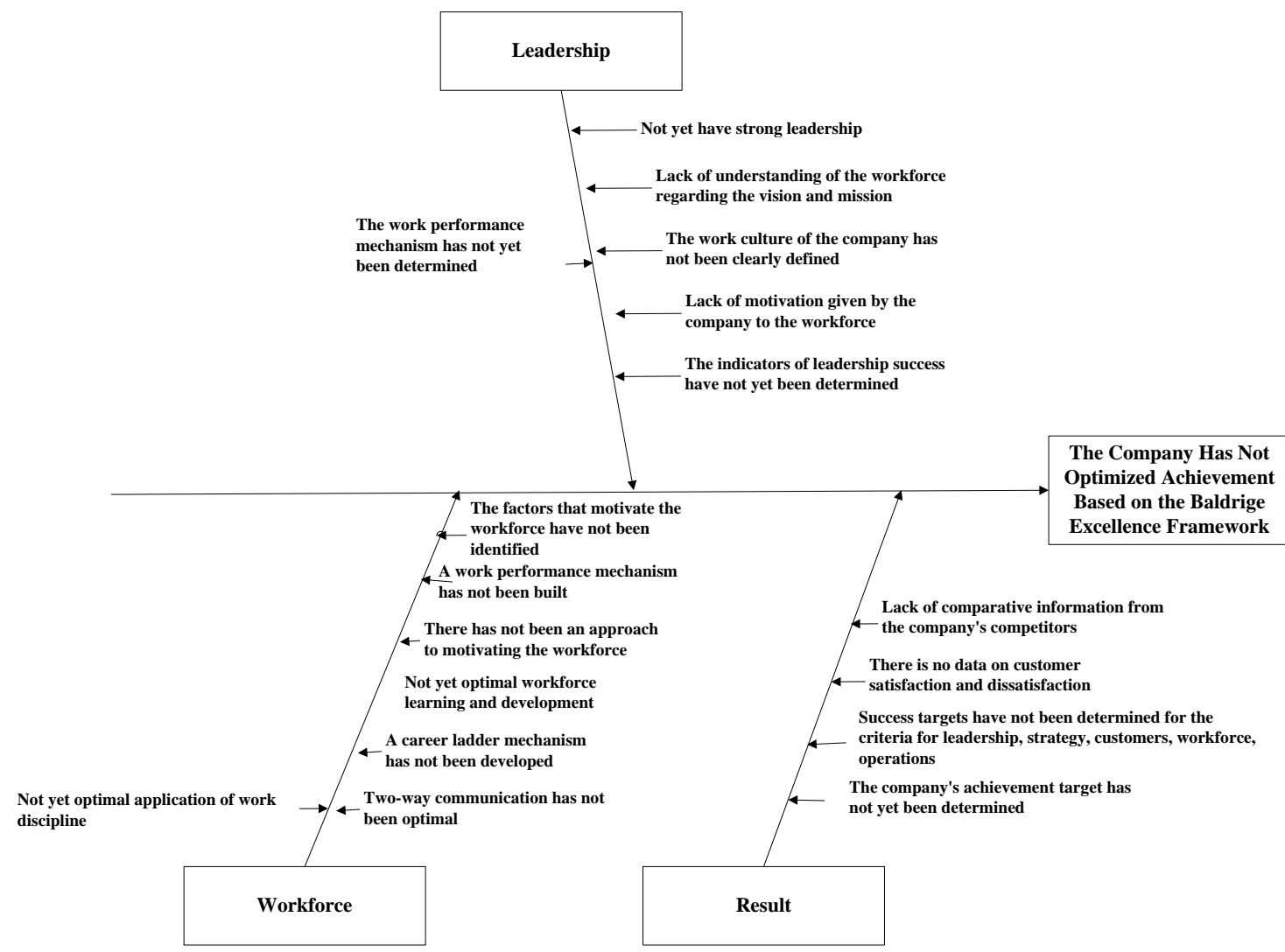

Figure 3 Fishbone Diagram for Leadership Criteria, Workforce Criteria and Outcome Criteria

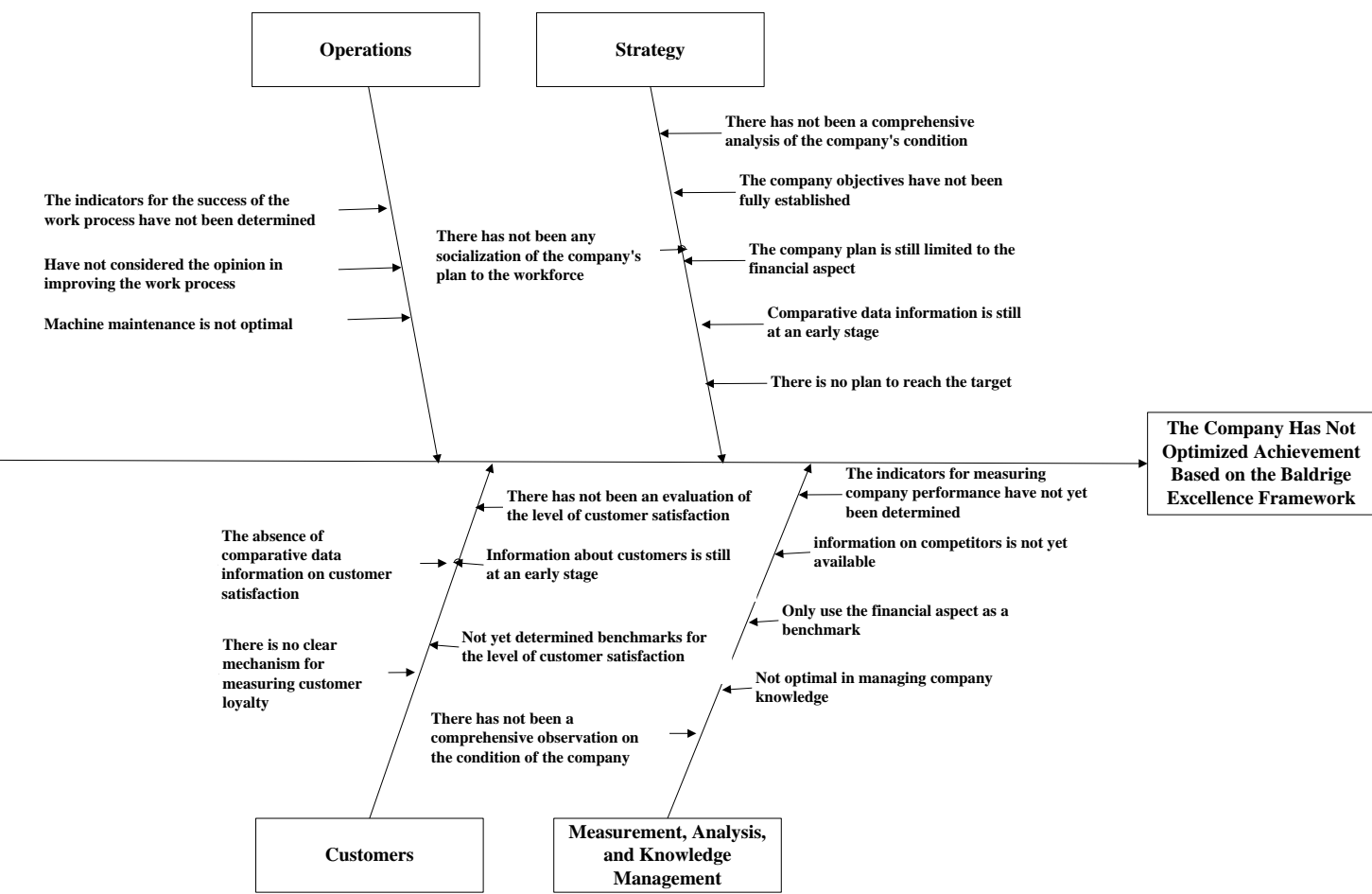

Figure 4 Fishbone Diagram for Strategy Criteria, Operations Criteria, Knowledge Management Criteria, and Customers Criteria 


\section{Conclusion}

Based on a comprehensive assessment conducted to determine the company's performance, the company got a value of 314.25 from maximum points of 1000. The company's position is at the Early Result level so that improvements are needed to increase the value acquisition. Based on the observations that have been made, the criteria for leadership, strategy, and workforce are the driving factors for others criteria in improving company performance. Therefore, the human resource factor influences improving the performance of this oil palm company.

\section{REFERENCES}

[1] M.A.N. Hasyim, "Pengukuran Kinerja Perusahaan Hotel Berdasarkan Kriteria Malcolm Baldrige", Jurnal Ecodemia, Vol. 2, no. 1, pp. 109-116. 2018.

[2] National Institute of Standards and Technology (NIST), "Baldrige Excellence Framework for Business, Nonprofit, Government”. 2019.

[3] M.M. Parast, "A Longitudinal Assessment of The Linkages Among The Baldrige Criteria Using Independent Reviewers' Scores”, Int. J. Production Economics, Vol. 164, pp. $24-$ 34. 2015.

[4] M.R. Jones, "Identifying Critical Factors That Predict Quality Management Program Success: Data Mining Analysis of Baldrige Award Data", The Quality Management Journal. Vol. 21, no. 3, pp. 49-61. 2014.

[5] C. Wiguna dan Y. Saintika, "Penerapan Malcolm Baldrige Dalam Sistem Penilaian Kinerja Manajemen Bidang Kesehatan", Jurnal Sistem Cerdas. Vol. 1, no. 1, pp. 10-17. 2018.

[6] I.K.A. Budiastawa dan R.A. Simanjuntak, "Pengukuran Kinerja Perusahaan Dengan Menggunakan Kriteria Malcolm Baldrige Guna Menentukan Level keunggulan". Prosiding Seminar Nasional Aplikasi Sains\&Teknologi (SNAST). 2014.

[7] M.N. Sintari dan A.W. Novitasari, "Hospital's Performance Measurement with Malcolm Baldrige Method in East Java", JPH RECODE, Vol. 3, no. 2, pp. 107-118. 2020.

[8] R. Arnenda dan A. Ikhwana, "Identifikasi Pencapaian Kinerja Perusahaan PT. Pindad (Persero) Dengan Menggunakan Metode Malcolm Baldrige", Jurnal Kalibrasi, Vol.12, no.1. 2014.

[9] H. Murnawan dan Mustofa, "Perencanaan Produktivitas Kerja Dari Hasil Evaluasi Produktivitas Dengan Metode Fishbone di Perusahaan Percetakan Kemasan PT.X", Jurnal Teknik Industri Heuristic, Vol. 11, no. 1, pp. 27-46. 2014.

[10] N. Matondang, et al, "Model Development Based on Baldrige Excellence Framework Criteria in Palm Oil Factory", Semirata International Conference on Science and Technology. 2018.

[11] M. Roberts, et al, "A Public Health Performance Excellence Improvement Strategy: Diffusion and Adoption of the Baldrige Framework Within Tennessee Department of Health", Journal of Public Health Management and Practice, Vol. 26, no. 1, pp. 39-45. 2020.

[12] A. Lazaros, et al, "Malcolm Baldrige National Quality Award (MBNQA) Dimensions in Greek Tertiary Education System", EBEEC Conference Proceedings. 2017. 